https://helda.helsinki.fi

Consumers as legitimating agents : How consumer-citizens challenge marketer legitimacy on social media

\title{
Lillqvist, Ella
}

2018-03

Lillqvist , E , Moisander , J K \& Firat , A F 2018 , ' Consumers as legitimating agents : How consumer-citizens challenge marketer legitimacy on social media ', International Journal of Consumer Studies , vol. 42 , no. 2 , pp. 197-204 . https://doi.org/10.1111/ijcs.12401

http://hdl.handle.net/10138/310004

https://doi.org/10.1111/ijcs.12401

acceptedVersion

Downloaded from Helda, University of Helsinki institutional repository.

This is an electronic reprint of the original article.

This reprint may differ from the original in pagination and typographic detail.

Please cite the original version. 


\title{
Consumers as legitimating agents: How consumer- citizens challenge marketer legitimacy on social media* $^{*}$
}

\author{
Ella Lillqvist $\dagger$, Consumer Society Research Centre, University of Helsinki, \\ Finland \\ Johanna Moisander, Department of Management Studies, Aalto University \\ School of Business, Finland \\ A. Fuat Firat, University of Texas Rio Grande Valley, Edinburg, USA
}

\begin{abstract}
Previous research has shown that consumers increasingly challenge the legitimacy of marketers and unsolicited marketing communication in online contexts. Based on a qualitative study, this article examines how and for what reasons consumers challenge marketer legitimacy-the perceived appropriateness of marketers and their activities - in the empirical context of Reddit, a popular social news and community website. The study suggests that consumers challenge or accept marketer legitimacy in online communities based on particular, community and situation specific, legitimacy criteria that reflect and reproduce the values and norms of the community. In doing so, it is argued, consumers play a role as legitimating agents-consumer-citizens that have the power to confer or deny legitimacy in the context of businesssociety relations. Overall, the study advances knowledge in the field of consumer studies in two ways. Firstly, it builds a symbolic interactionist perspective on consumer-citizens as legitimating agents who enact their active citizenship role in the marketplace by assessing and constructing marketer legitimacy in online communities. Secondly, it offers an empirically grounded account of how and for what reasons consumer-citizens challenge or accept the legitimacy of marketers and unsolicited marketing communication in online communities.
\end{abstract}

\section{Keywords}

ad avoidance, consumer-citizens, online community, organizational legitimacy, social media, symbolic interactionism

* This is the peer reviewed version of the following article: Lillqvist, E., Moisander, J. K., \& Firat, A. F. (2018). Consumers as legitimating agents: How consumercitizens challenge marketer legitimacy on social media. International Journal of Consumer Studies, 42(2), 197-204. doi:10.1111/ijcs.12401. It has been published in final form at http://onlinelibrary.wiley.com/doi/10.1111/ijcs.12401/full. This article may be used for non-commercial purposes in accordance with Wiley Terms and Conditions for Use of Self-Archived Versions.

† Corresponding author: Ella Lillqvist, ella.lillqvist@helsinki.fi 


\section{Introduction}

Research shows that consumers are increasingly critical of unsolicited marketing communication (e.g. Wible, 2011, Sher, 2011, Yu and Cude, 2009) because they feel that these messages represent a blatant intrusion into their private spaces and that marketers merely try to persuade them to buy things that they do not need or want (O'Malley et al., 1997, O'Malley and Prothero, 2004, Fransen et al., 2015). Particularly in social media, consumers often view advertisers as uninvited intruders (Amezcua and Quintanilla, 2016, Fournier and Avery, 2011, Campbell et al., 2014). As Fournier and Avery (2011) have argued, the Internet was 'created not to sell branded products, but to link people together'. As a result, consumers have started to avoid advertising by using, for example, browsers that support a 'do not track' option and ad blocker software (Baek and Morimoto, 2012, Fransen et al., 2015). What is more, some aggravated consumer-citizens have also developed strategies for more actively resisting advertising by publicly voicing counter-arguments and questioning the credibility, trustworthiness, and motives of advertisers as participants in online communities (Fransen et al., 2015).

In this paper, we investigate this critical consumer activity in online environments as a manifestation of the active citizenship roles that consumers play in the marketplace. By active citizenship we refer to the roles and responsibilities that consumers assume as they pursue their civic interests and actively participate in the public arena as citizens (McShane and Sabadoz, 2015, Rokka and Moisander, 2009, Firat and Dholakia, 2016). Several scholars have demonstrated that the Internet and social media have reconfigured the relationship between marketers and consumers, for example by providing platforms for consumer communities to form and thereby magnifying consumer voice in the marketplace (Denegri-Knott, 2006, Gensler et al., 2013). It has thus been argued that consumers become 'empowered' (Rezabakhsh et al., 2006), as 'prosumers' (Ritzer and Jurgenson, 2010) or 'strategic agents' (Moisander et al., 2013). But we still do not fully understand the societal dimensions and implications of these developments. We know particularly little about the ways in which active consumer-citizens participate in legitimacy struggles over acceptable business practice. In this paper, we set out to explore and better understand these legitimacy struggles in the context of marketing, unsolicited marketer presence and marketing communication in online communities in particular.

More specifically, we draw on theories of organizational legitimacy (Weber, 1978, Suchman, 1995) and symbolic interactionism (Goffman, 1959, Blumer, 1969) to explore how and for what reasons consumers challenge marketer legitimacy - the 'perceived appropriateness' of marketers and their activities in terms of the 'rules, values, norms, and definitions' of a particular social system (Deephouse et al., 2017: 32) -in the empirical context of Reddit, a popular social news and community website consisting of various subcommunities. Symbolic interactionism, a sociological theory based on the idea that meaning is created in interaction and through interpretation (Blumer, 1969), allows us to shed light on marketer legitimacy as socially constructed by groups of people, in congruence with the social norms and values (Suchman, 1995, Deephouse et al., 2017) that apply in particular interactional situations (Goffman, 1959, Blumer, 1969). From this perspective, we view consumers as legitimating agents who have the power to confer or deny legitimacy in the context of business-society relations through processes of social construction. 
The empirical study on which the paper is based focuses on consumers' reactions to marketer presence on Reddit. Reddit represents a particularly illuminating empirical setting for our study because it is an online community website that is not controlled by marketers, and because it offers an interactive environment for consumers to express their views about posted content by both discussing and voting on it. Based on a qualitative analysis of marketers' posts and consumer comments on those posts on Reddit, the study shows how consumers assess marketer legitimacy based on particular community and situation specific legitimacy criteria that reflect and reproduce the communal values and norms of the community. Specifically, the analysis shows how in Reddit communities, consumers confer legitimacy based on particular instrumental, moral, and relational types of socially shared legitimacy criteria and challenge marketer legitimacy when marketers' activities are in conflict with these criteria.

Our paper contributes to the literature on consumer studies in two main ways. First, the paper proposes a symbolic interactionist perspective on active consumer-citizens as legitimating agents. Second, the article offers an empirically grounded account of how and for what reasons consumers challenge or accept the legitimacy of unsolicited marketer presence in online communities. In doing so, we thus extend understanding of the various ways that consumers can affect change on an institutional level, even in largely uncoordinated ways, through their micro-level practices (Ansari and Phillips, 2011, Dolbec and Fischer, 2015) in online environments.

\section{Interactionist Perspective on Consumer-Citizens as Legitimating Agents}

In building our theoretical perspective on consumer-citizens as legitimating agents on social media, we integrate theoretical ideas from the literature on organizational legitimacy (Deephouse et al., 2017, Scott, 2014, Suchman, 1995, Weber, 1978) and symbolic interactionism (Goffman, 1959, Blumer, 1969). The symbolic interactionist approach is particularly useful for exploring processes of legitimation in the context of social media due to the importance of interaction in these media. Symbolic interactionism also ideally complements other institutional approaches to legitimacy as it draws attention to the microlevel of day-to-day activities and interactions as constitutive of legitimacy (Barley, 2008, Hallett et al., 2009). In the following paragraphs, we briefly discuss the key elements of our theoretical perspective.

\section{Organizational Legitimacy}

Organizational legitimacy is defined as 'the perceived appropriateness of an organization to a social system in terms of rules, values, norms, and definitions' (Deephouse et al., 2017, see also Suchman, 1995). Scholarly interest in questions of organizational legitimacy stems from the idea that organizations need 'cultural support' from their environment (Deephouse et al., 2017) - they depend for survival on relations they maintain with their surroundings (Scott and Davis, 2007) —and legitimacy has also been found to enhance financial performance and strategic choice (Deephouse et al., 2017).

Legitimacy is conferred by various 'sources'-also sometimes referred to as 'audiences' or 'evaluators' (Bitektine, 2011)—namely collective and individual actors inside or outside the organization who observe and evaluate it more or less actively and in a way that generalizes into a broader consensus of the appropriateness of the organization (Deephouse et al., 2017). Examples 
of such actors include government agencies, the media, and the public at large. We prefer to call these sources 'legitimating agents,' as this term foregrounds the social process involved (legitimation) and the active involvement (agency) of these actors, consumer-citizens in our case.

The criteria used by legitimating agents to evaluate organizations are based on the prevailing 'rules of the game' (McAdam and Scott, 2005) or 'cultural-cognitive frameworks' (Scott, 2014), which provide templates to interpret reality and judge what constitutes appropriate action in a particular context. Several types of criteria have been discerned, including regulatory, pragmatic, normative and cultural-cognitive (Deephouse et al., 2017). Based on previous research within neo-institutional and social psychologist approaches to legitimacy, Tost (2011) highlights three types of criteria which are particularly relevant where individual legitimating agents and active evaluations are concerned. These legitimacy criteria include instrumental (i.e. pragmatic) criteria which are based on self-interested considerations of the legitimating agent, moral criteria which refer to a wider social good, and relational criteria which refer to how the organization supports the identity and self-worth of individuals in relations with them (Tost, 2011).

\section{Symbolic Interactionism}

Symbolic interactionism is a micro-sociological theory investigating human group life, based on the idea that meaning is created in interaction and through interpretation (Blumer, 1969). While symbolic interactionism emphasizes the agency of the individual in social situations, i.e. the individual's capability to make a difference and, to some extent at least, shape social reality, an interactionist view also acknowledges that various cultural and ideological 'structures' or 'practices' create momentum for individuals to proceed towards certain directions in new situations.

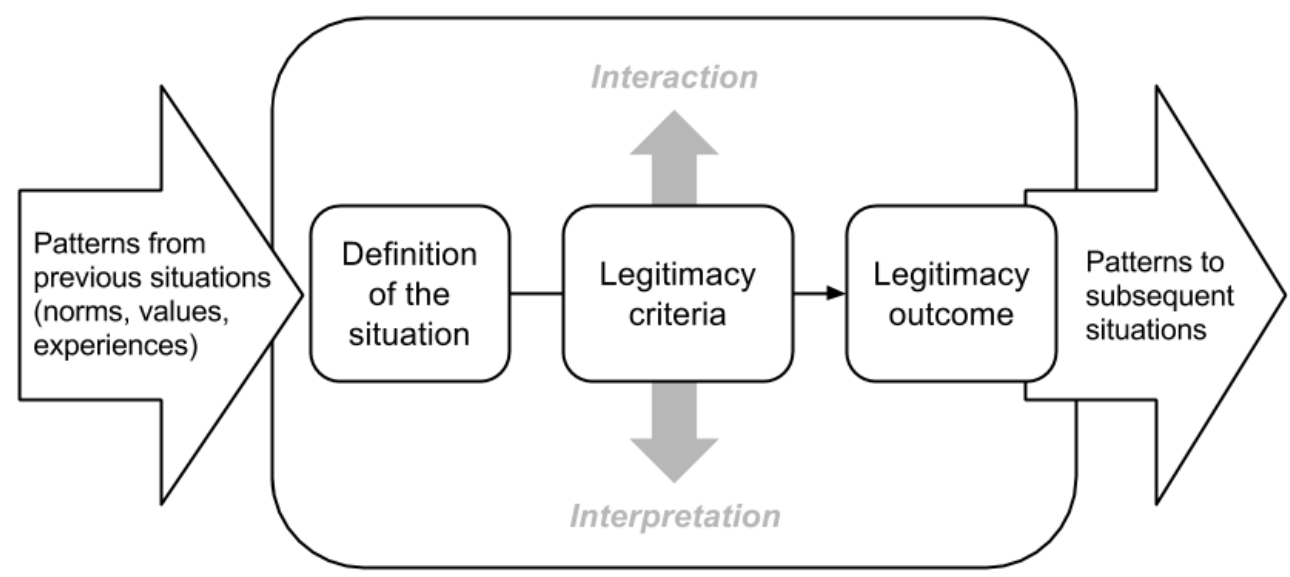

Figure 1. Construction of marketer legitimacy in specific situations.

Figure 1 summarizes our theoretical framework, illustrating our situational, micro-level understanding of legitimacy as negotiated in interaction (see also Barley, 2008, Hallett et al., 2009). In building this framework, we draw particularly on the basic interactionist idea that social interaction always involves interpretation of the meaning of others' actions and remarks and definition of the situation, namely an understanding of what type of a social situation the participants are involved in, and which social rules and expectations therefore apply (Goffman, 1959, Blumer, 1969). To be smooth, an 
interaction situation should be similarly defined by all participants from the start, as revising the definition during the interaction can be difficult and lead to embarrassment for the one whose definition is rejected (Goffman, 1959).

In the interaction processes where legitimacy is formed, as Figure 1 illustrates, legitimacy criteria are another central component. These criteria are based on the norms, values, and shared experiences of the community (large arrow on the left), and they vary according to social situations, specifically participants' definitions of those social situations. Marketer legitimacy is socially constructed in each interaction situation, but a trace also carries over to future situations by providing expectations and (re)constructing norms and values (large arrow on the right). Thus, it can be argued that what happens in individual situations eventually coalesces to recurrent, macro-level patterns of marketer legitimacy (Bitektine and Haack, 2015).

To answer our research question-how and for what reasons consumers challenge marketer legitimacy-we focus in our analysis on the factors that influence consumers' interpretation of marketer legitimacy. These include legitimacy criteria, which are based on norms, values and shared experiences, and the definitions of situations - how interactional situations on Reddit are understood and whether the marketers and consumers understand them in the same way.

\section{Data and Method}

A qualitative study of consumer reactions to marketers on Reddit was conducted to answer our research questions. Reddit.com, the context for this study, is a social news and community website, meaning it is mainly focused on linking to and discussing content from other sites, but it is also a platform where anyone can easily create their own communities, 'subreddits', around specific topics (Massanari, 2017). User accounts are pseudonymous and users subscribe to subreddits instead of forming networks with other users; thus, the site has little in common with social networking sites (e.g. Facebook) that much of previous social media research has focused on (e.g. Lillqvist and Louhiala-Salminen, 2014). Subreddits focus on varied topics and are independently moderated, but they often reflect 'geek interests'-technology, science, popular culture, and gaming (Massanari, 2017). A crucial feature of Reddit is that the users, referred to as 'Redditors,' get to 'up-vote' or 'downvote' posts, thus jointly influencing what can be seen on the site's front page.

Marketing on Reddit can be done using both sponsored posts and regular posts. Some traditional ads also exist, but we have excluded them from the study and focus only on those types of marketing communication that allow for consumer discussions about the posts. One particular type of (nonsponsored) post that is sometimes used for marketing is an AMA (Ask Me Anything), where Redditors ask questions to the poster. Another common type of post is a link post, where an outside source is linked and functions as the topic of discussion.

The data collected from Reddit include posts and related consumer discussions that occurred in three types of contexts, namely sponsored posts, AMAs with marketing content, and link posts with marketing content. We also collected other (consumer-initiated) discussions about marketing activity on Reddit, as well as the rules and instructions from Reddit wiki concerning behavior on Reddit in general and marketing in particular. Including these five types of material provided us with rich data and the ability to examine different kinds of communication situations on Reddit. See Table 1 for data 
types, sources, and amounts.

\begin{tabular}{|l|l|l|}
\hline Type & Pages & Sources \\
\hline Sponsored posts & 61 & Sponsored posts \\
\hline AMAs & 295 & r/IAmA, r/Minecraft \\
\hline Link posts & 14 & $\begin{array}{l}\text { r/androiddev, r/sanfrancisco, } \\
\text { r/canada }\end{array}$ \\
\hline Discussions about marketing on Reddit & 37 & $\begin{array}{l}\text { r/TheoryOfReddit, } \\
\text { r/HailCorporate, r/Android }\end{array}$ \\
\hline Reddit rules & 15 & Reddit wiki \\
\hline Total & $\mathbf{4 2 2}$ & \\
\hline
\end{tabular}

Table 1. The data.

In an iterative process of close reading, we read through the data to pinpoint sections that were relevant for answering the research question, particularly focusing on consumers' legitimacy criteria and definitions of situations. We identified 'first order codes' (Van Maanen, 1979, Gioia et al., 2013), expressions that consumers used relating to these aspects. We will endeavor to conserve these participant voices in the Findings section as short italicized expressions and as longer numbered quotes. After this initial coding, we began grouping the codes into fewer categories, 'second order themes' (Gioia et al., 2013). As a result of this phase, we had 13 themes: two themes regarding participants' preconceptions, namely their views on marketing and their previous experiences concerning marketers and products, six themes related to legitimacy criteria (quality, relevance, honesty, selflessness, respect, and participation), and five themes concerning definitions of the situations (marketer involved, no marketer involved, link post, AMA, sponsored post). Subsequently, as we began to assemble these codes into 'aggregate dimensions' (Gioia et al., 2013), we realized that the six themes related to legitimacy criteria fit into the categories of instrumental, moral, and relational legitimacy. We will use these three categories to organize the next section as we elaborate on the findings.

\section{Findings}

Based on our empirical analysis, and the theoretical framework that we build, we now show how and for what reasons consumers challenge marketer legitimacy. We focus on how three types of legitimacy criteria-instrumental, moral, and relational - were used by consumers to assess marketer legitimacy on Reddit, and discuss definitions of situations in this interpretative process. In Figure 2, we present a summary of our findings. See also the Appendix for additional supporting evidence. 


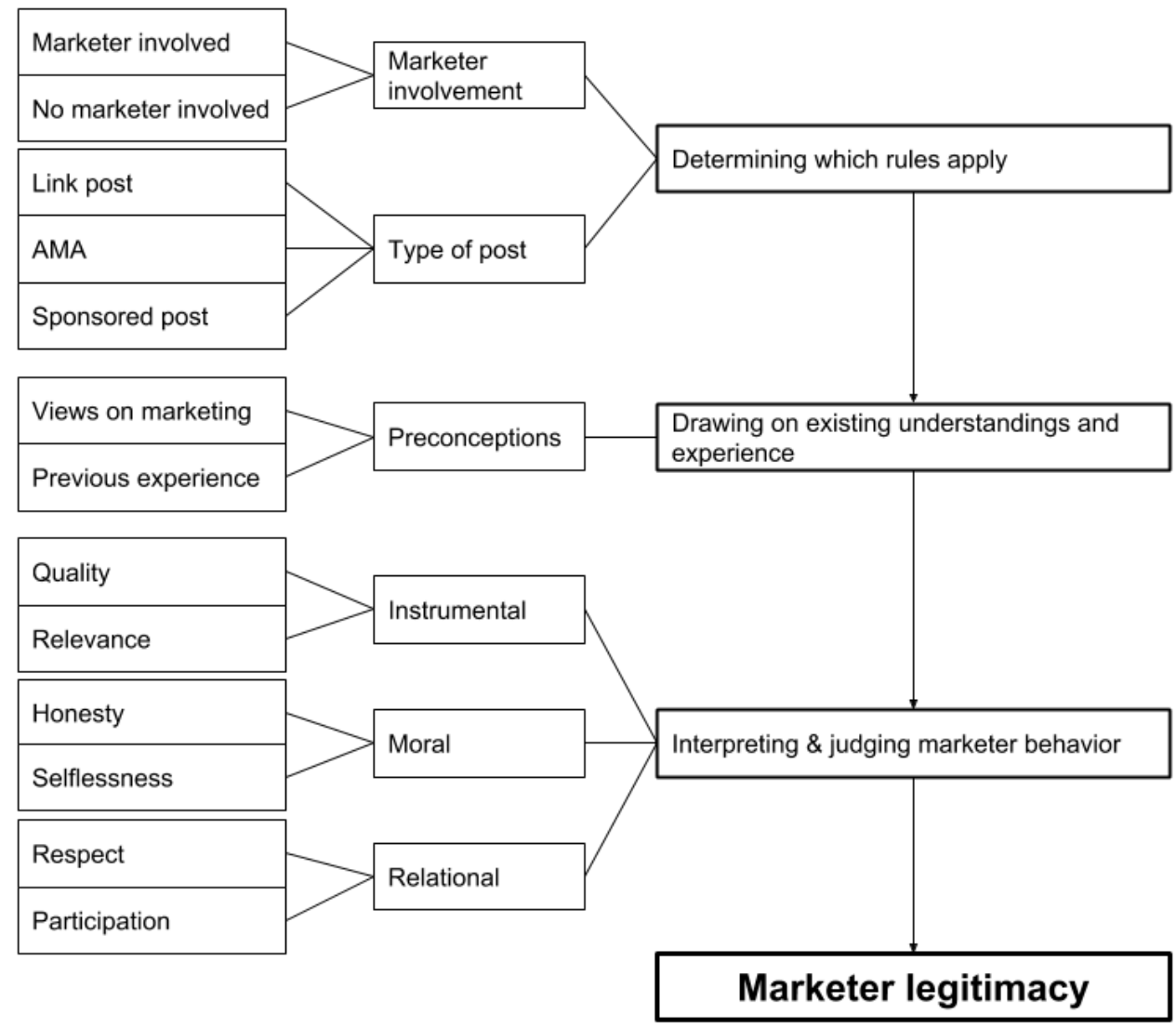

Figure 2. Forming marketer legitimacy on Reddit.

Overall, our empirical analysis shows that consumers' definitions of situations on Reddit involve at least determining whether a post contains marketing communication and what kind of post it is. This definition forms the basis for the interaction as it determines what kind of norms and expectations apply. The expectations formed by previous experiences (e.g. with the marketer, the product, or other marketers in similar situations) are therefore also important. Overall, our data shows that when situations are defined as marketing or promotional content on Reddit, consumers commonly react negatively. This inherent lack of marketer legitimacy was described by users for example as staunchly anti-ad tendencies or an adblock mentality. However, there were many exceptions to this negative view, such as cases where the marketing is less recognizable so that the consumers do not define the situation as marketing in the first place.

\section{Instrumental Legitimacy}

In our data, we found that consumers evaluated marketers based on the quality of the marketer's communication or products as well as on their relevance or usefulness for the consumers in the context; these are instrumental legitimacy criteria. When marketing content was deemed to be of good quality it was interpreted and described in positive terms, for example as original, interesting, or funny, as opposed to as garbage or pointless. Instrumental legitimacy was also conferred by consumers when marketing communication was interpreted as relevant to them in the context, for example as useful or appropriate content for the subreddit it was submitted to.

In many cases, we could see that when a situation was defined as an 
attempt at marketing, shared negative expectations and views about marketing were being evoked, even in cases that were deemed as exceptions to that general rule:

\section{Extract 1}

And as far as advertising goes, this one is actually pretty interesting and useful.

In Extract 1, the consumer places the marketer's post within a reference group of advertising and construes the judgment-that it is interesting and usefulas contrary to expectation. The assessment of legitimacy, therefore, is limited to this specific case. It is noteworthy that this marketer, offering online courses, also introduced the sponsored post by emphasizing the benefits for consumers: the site was described as free and the courses as potentially leading to real college credit. There is, then, a good alignment between the approach taken by the marketer in this case and the positive instrumental legitimacy judgment by the consumers.

\section{Moral Legitimacy}

In our data, we found that consumers also largely conferred legitimacy on the bases of moral criteria; honesty and selflessness in particular. Consumers' perceptions of the (un)trustworthiness of marketing has been discussed before (e.g. Kelly et al., 2010), but in our data it is noteworthy that honesty referred mainly to openness regarding the fact that some post was in fact promotional, rather than to whether the content itself was reliable. Marketers were often evaluated as (dis)honest (misleading, disingenuous, or fake). One sponsored post, for example, was called viral marketing bullshit by some consumers, referring to stealthy marketing communication (viral marketing) dishonestly posing as regular content. However, in this case, definitions of the situation differed as several other users intervened to point out that sponsored posts are not 'viral,' they are honest advertising - thereby supporting the legitimacy of this marketer.

In another case, the Canadian Broadcasting Company (CBC) introduced a mobile application in a regular link post, without trying to hide their identity and the fact that they were promoting their own application. The response was overwhelmingly positive:

\section{Extract 2}

This was not a quietly nefarious viral ad or astroturfing. It was honest promotion by one part of a public institution that's under death by a 1000 cuts, and probably trying to assert that they are still relevant for the Internet age.

One of the key elements widely discussed by consumers in this case was indeed the CBC's honest approach. Here as well, upfront promotion is contrasted with another option that is presented as worse, namely viral advertising or astroturfing that aims to mislead by posing as consumer content. Marketing in both sponsored and regular posts can, then, be deemed legitimate based on moral criteria, although the basic principle according to the rules of Reddit is that marketing should take place through the paid format.

The second category of moral legitimacy criteria, selflessness, refers to whether the marketer is seen to profit financially from their own post. This 
can also be illustrated using the $\mathrm{CBC}$ case where, in addition to honesty, a central point that consumers brought up was that the CBC was not trying to exploit the Reddit community for profit; this seems to be the reason why they accepted this instance of marketing in a regular post. Extract 3 suggests a degree of sympathy for a struggling public institution, and many consumers pointed out that $\mathrm{CBC}$ was not aiming to make money with the application they were promoting:

\section{Extract 3}

The CBC is intending to lose money with this app. To compare it to a for-profit company spamming Reddit is ridiculous.

This extract exemplifies what seems to be a common community value on Reddit, namely a positive view towards losing money as compared to making money, and public organizations as compared to private ones. Being a public broadcaster and providing content for free, the CBC was interpreted as unselfish and therefore a legitimate participant on Reddit.

\section{Relational Legitimacy}

In our data, the third category of legitimacy criteria, relational legitimacy, comprised respect and participation. One example where a lack of respect was a key point in consumers of legitimacy was an AMA with actor Woody Harrelson. The Redditors commenting were practically unanimous that this was probably the worst AMA they had ever read. The star refused to answer any question not related to his latest movie, explaining in a comment: $i$ consider my time valuable. Many Redditors seemed to take offense and voted that comment down by a landslide, describing it as insulting. Considering the participants' definitions of the situation helps understand these events. In Extract 4 Harrelson answers a question as to whether he had been aware of Reddit before doing the AMA.

\section{Extract 4 \\ Harrelson: I know Oren Moverman did an interview here. I did just learn about it, so I'm trying. \\ Redditor: 'Interview'? This ain't no interview, kid, this is an internet forum where the browsers will ask you anything they want because you told them to (AMA - Ask Me Anything). This is not some crappy front for advertising your new movie, because no one really cares about it.}

The extract demonstrates that Harrelson and the consumers had very different definitions of the situation. This kind of mismatch of definitions can be highly problematic, because legitimacy criteria are context-specific: a wrong definition of a situation can lead to inappropriate behavior. For example, the power dynamic between Hollywood actors and journalists might allow the star to refuse to answer certain questions, but in an AMA on Reddit, consumers have the upper hand, and the basic premise is that all questions should be allowed and many of them should be answered.

Our data suggests that active participation is expected in this social media context. This can be illustrated by AMAs concerning the web browsers IE, Opera, and Firefox. The first of these, IE, failed in the eyes of the Reddit users; the main problem was a failure to meet expectations concerning participation: Answers in a marketing communication style were considered 
insufficient in the context, and promised follow-up answers were never given. Thus, the unfolding of the discussion did not correspond to consumers' expectations based on the initial definition of the situation as an AMA.

Besides active participation in a specific situation, such as an AMA, longer term participation is also important. It can provide marketers with knowledge of previous marketing situations which enable them to adjust to consumer expectations. For example, knowledge of IE's unsuccessful AMA provided Opera and Firefox valuable information for doing their own AMAs. In fact, Opera made it clear already in the title of their post that their AMA team had more engineers than marketers. Both the Opera and Firefox AMAs were interpreted very positively by consumers, with recurring comparisons to the earlier disappointment with IE. This shows the importance of shared understandings stemming from earlier situations; they provide a comparative basis for consumers' judgments of marketer legitimacy.

Longer term participation on Reddit is also appreciated by Redditors. Extract 5 is from an AMA with Markus Persson, also known as Notch, the creator of a popular video game called Minecraft.

\section{Extract 5}

Redditor: Hi Notch, I was wondering, what do you do at home when you're not working?

Persson: I refresh reddit over and over and over, in like four different windows.

Redditor: ONE OF US, ONE OF US.

The last comment suggests that Persson was seen as belonging to the community, and not there for the sole purpose of promoting the game. Therefore, he was accepted as a legitimate participant.

Our findings point to the importance of both the quality and the quantity of marketer participation, as well as the importance of participation not only within a specific communication situation, but also across a longer period where marketers can accumulate legitimacy over time. Respect towards consumers, or 'manners,' is also an interesting point. It sounds obvious that one should be respectful to be accepted in interaction situations, but our analysis suggests that differing understandings of the nature of the situation can complicate following this principle.

\section{Discussion and Conclusion}

In this paper, we set out to better understand how consumers enact their active citizenship role by participating in legitimacy struggles over marketer presence and unsolicited marketing communication in online communities. Specifically, our aim was to study how and for what reasons consumers challenge marketer legitimacy in the empirical context of the popular news and community website Reddit. Based on our study, we offer two main contributions to the literature on consumer studies.

First, we elaborate theory on consumers as active citizens (McShane and Sabadoz, 2015, Rokka and Moisander, 2009, Firat and Dholakia, 2016) by building a symbolic interactionist perspective on consumers as legitimating agents. The approach allows us to look at the phenomenon of consumer resistance to marketing from a societal perspective, as a way for consumers to participate in business-society relations. This perspective therefore shifts attention to the ways in which consumer-citizens participate in public debate 
on the confines of acceptable business practice. More specifically, as our empirical study demonstrates, this approach allows us to better understand the negotiated, social, and situational nature of consumers' legitimacy judgments in online communities. In doing so, our study thus advances knowledge of the ways in which consumers can, through their micro-level practices, affect change on an institutional level even in largely uncoordinated ways (Ansari and Phillips, 2011, Dolbec and Fischer, 2015).

Second, our study contributes to the literature on consumer resistance to-or acceptance of-advertising (O'Malley et al., 1997, O'Malley and Prothero, 2004, Fransen et al., 2015, Amezcua and Quintanilla, 2016) and social media marketing (Saxena and Khanna, 2013, Taylor et al., 2011, Kelly et al., 2010) by offering an empirically grounded understanding of how and for what reasons consumers challenge or accept the legitimacy of marketer presence and unsolicited marketing communication in online communities. Our findings show, in particular, how consumers assess the legitimacy of marketers and their activities in online environments on the basis of three types of criteria, namely instrumental (quality, relevance), moral (honesty, selflessness), and relational (respect, participation) considerations. While prior research has shed light on instrumental concerns that underpin consumer acceptance of marketing communication, such as information and entertainment value (Saxena and Khanna, 2013, Heinonen, 2011, Taylor et al., 2011, Kelly et al., 2010), our study shifts attention to, and empirically elaborates on, the ways in which particular context-specific moral and relational considerations shape the processes through which consumers confer legitimacy on marketers and their activities in online environments.

Consequently, our study suggests that while consumers tend to see the unsolicited presence of marketers in online communities as illegitimate, their perceptions and reactions may well vary significantly depending on the communication situation and the norms and values that apply in the setting. Our findings thus challenge the idea, recently proposed by Campbell and colleagues (2014), that online and social media consumers can be segmented based on their general attitudes and reactions to social media marketing. Specifically, our findings call into question the basic assumption that underlies this idea - that consumers' attitudes and reactions to social media marketing are essentially the same regardless of context. Our study highlights, by contrast, that consumers' perceptions of and reactions to marketing activities vary from situation to situation and context to context, depending on how well the activities fit the legitimacy criteria that are relevant in the specific situation and context in which marketers and consumers interact.

To conclude, our paper thus highlights the active roles that consumers play as citizens in the ever-proliferating online and social media environments of the contemporary marketplace. We argue that by conferring legitimacy on marketers and their activities in online communities, consumers may operate as legitimating agents who pursue their civic interests and actively participate in the public arena as citizens. For the future development of the theory on consumers as active citizens, therefore, we recommend that consumer science scholars continue exploring the micro-level of how consumers and marketers actually interact in various types of online communities, and the practices that consumers engage in to challenge organizations and their marketers in online environments. 


\section{References}

Amezcua, B. \& Quintanilla, C. (2016) When eWOM becomes cynical. International Journal of Consumer Studies, 40, 290-298.

Ansari, S. \& Phillips, N. (2011) Text me! New consumer practices and change in organizational fields. Organization Science, 22, 1579-1599.

Baek, T. H. \& Morimoto, M. (2012) Stay away from me. Journal of Advertising, 41, 59-76.

Barley, S. R. (2008) Coalface institutionalism (ed. by Greenwood, R., Oliver, C., Sahlin, K. \& Suddaby, R.), pp. 491-518. Sage, Thousand Oaks, CA.

Bitektine, A. (2011) Toward a theory of social judgments of organizations: The case of legitimacy, reputation, and status. Academy of Management Review, 36, 151179.

Bitektine, A. \& Haack, P. (2015) The "macro" and the "micro" of legitimacy: Toward a multilevel theory of the legitimacy process. Academy of Management Review, 40, 49-75.

Blumer, H. (1969) Symbolic interactionism. Perspective and method. Prentice-Hall, Englewood Cliffs, NJ.

Campbell, C., Ferraro, C. \& Sands, S. (2014) Segmenting consumer reactions to social network marketing. European Journal of Marketing, 48, 432-452.

Deephouse, D. L., Bundy, J., Tost, L. P. \& Suchman, M. C. (2017) Organizational legitimacy: Six key questions (ed. by Greenwood, R., Oliver, C., Lawrence, T. \& Meyer, R.), pp. 27-54. Sage, London.

Denegri-Knott, J. (2006) Consumers behaving badly: deviation or innovation? Power struggles on the web. Journal of Consumer Behaviour, 5, 82-94.

Dolbec, P.-Y. \& Fischer, E. (2015) Refashioning a field? Connected consumers and institutional dynamics in markets. Journal of Consumer Research, 41, 1447-1468.

Firat, A. F. \& Dholakia, N. (2016) From consumer to construer: Travels in human subjectivity. Journal of Consumer Culture, published online ahead of print.

Fournier, S. \& Avery, J. (2011) The uninvited brand. Business Horizons, 54, 193-207.

Fransen, M. L., Verlegh, P. W. J., Kirmani, A. \& Smit, E. G. (2015) A typology of consumer strategies for resisting advertising, and a review of mechanisms for countering them. International Journal of Advertising, 34, 6-16.

Gensler, S., Völckner, F., Liu-Thompkins, Y. \& Wiertz, C. (2013) Managing brands in the social media environment. Journal of Interactive Marketing, 27, 242-256.

Gioia, D. A., Corley, K. G. \& Hamilton, A. L. (2013) Seeking qualitative rigor in inductive research. Organizational Research Methods, 16, 15-31.

Goffman, E. (1959) The presentation of self in everyday life. Doubleday, Garden City, NY.

Hallett, T., Shulman, D. \& Fine, G. A. (2009) Peopling organizations: The promise of classic symbolic interactionism for an inhabited institutionalism (ed. by Adler, P. S.), pp. 486-509. Oxford University Press, Oxford, UK.

Heinonen, K. (2011) Consumer activity in social media: Managerial approaches to consumers' social media behavior. Journal of Consumer Behaviour, 10, 356-364.

Kelly, L., Kerr, G. \& Drennan, J. (2010) Avoidance of advertising in social networking sites. Journal of Interactive Advertising, 10, 16-27.

Lillqvist, E. \& Louhiala-Salminen, L. (2014) Facing Facebook: Impression management strategies in company-consumer interactions. Journal of Business and Technical Communication, 28, 3-30.

Massanari, A. (2017) \#Gamergate and The Fappening: How Reddit's algorithm, governance, and culture support toxic technocultures. New Media \& Society, 19, 329-346.

McAdam, D. \& Scott, W. R. (2005) Organizations and movements (ed. by Davis, G. F., 
McAdam, D., Scott, W. R. \& Zald, M. N.), pp. 4-40. Cambridge University Press, New York.

McShane, L. \& Sabadoz, C. (2015) Rethinking the concept of consumer empowerment: recognizing consumers as citizens. International Journal of Consumer Studies, 39, 544-551.

Moisander, J., Könkkölä, S. \& Laine, P.-M. (2013) Consumer workers as immaterial labour in the converging media markets: three value-creation practices. International Journal of Consumer Studies, 37, 222-227.

O'Malley, L., Patterson, M. \& Evans, M. (1997) Intimacy or intrusion? The privacy dilemma for relationship marketing in consumer markets. Journal of Marketing Management, 13, 541-559.

O'Malley, L. \& Prothero, A. (2004) Beyond the frills of relationship marketing. Journal of Business Research, 57, 1286-1294.

Rezabakhsh, B., Bornemann, D., Hansen, U. \& Schrader, U. (2006) Consumer Power: A Comparison of the Old Economy and the Internet Economy. Journal of Consumer Policy, 29, 3-36.

Ritzer, G. \& Jurgenson, N. (2010) Production, consumption, prosumption: The nature of capitalism in the age of the digital 'prosumer'. Journal of Consumer Culture, 10, 13-36.

Rokka, J. \& Moisander, J. (2009) Environmental dialogue in online communities: negotiating ecological citizenship among global travellers. International Journal of Consumer Studies, 33, 199-205.

Saxena, A. \& Khanna, U. (2013) Advertising on social network sites: A structural equation modelling approach. Vision, 17, 17-25.

Scott, W. R. (2014) Institutions and organizations: Ideas, interests, and identities, 4th edn. SAGE Publications, Thousand Oaks, CA.

Scott, W. R. \& Davis, G. F. (2007) Organizations and organizing: Rational, natural, and open system perspectives. Prentice Hall, New York.

Sher, S. (2011) A framework for assessing immorally manipulative marketing tactics. Journal of Business Ethics, 102, 97-118.

Suchman, M. C. (1995) Managing legitimacy: Strategic and institutional approaches. Academy of Management Review, 20, 571-610.

Taylor, D. G., Lewin, J. E. \& Strutton, D. (2011) Friends, fans, and followers: Do ads work on social networks? Journal of Advertising Research, 51, 258-275.

Tost, L. P. (2011) An integrative model of legitimacy judgments. Academy of Management Review, 36, 686-710.

Van Maanen, J. (1979) The fact of fiction in organizational ethnography. Administrative Science Quarterly, 24, 539-550.

Weber, M. (1978) Economy and society: an outline of interpretive sociology. California Press, University of Berkeley, CA.

Wible, A. (2011) It's all on sale: Marketing ethics and the perpetually fooled. Journal of Business Ethics, 99, 17-21.

Yu, J. \& Cude, B. (2009) 'Hello, Mrs. Sarah Jones! We recommend this product!' Consumers' perceptions about personalized advertising: comparisons across advertisements delivered via three different types of media. International Journal of Consumer Studies, 33, 503-514. 


\section{Appendix: Supporting Evidence}

\begin{tabular}{|c|c|}
\hline \multicolumn{2}{|c|}{ Instrumental legitimacy } \\
\hline Quality & $\begin{array}{l}\text { - If the content is good, I'm happy the creator submitted it } \\
\text { - It's just silly marketing babble changing the topic. } \\
\text { - redditors don't care that you have something to promote, they care } \\
\text { what you think and that you have interesting things to say. } \\
\text { - I don't think anyone would be angry about that. Even less so if it } \\
\text { was a really funny advertisement. }\end{array}$ \\
\hline Relevance & $\begin{array}{l}\text { - I think if it's a useful ad, and not a trick, then it's fine. } \\
\text { - If it is appropriate content for the subreddit it is submitted to then } \\
\text { I am less concerned with who submitted or what their ultimate goal } \\
\text { was. } \\
\text { - I don't use adblock on Reddit and I will even click on } \\
\text { advertisements that I think are relevant to me. } \\
\text { - This whole AMA is a good example of how not to use the internet } \\
\text { for marketing. It seems clear that the whole post was an attempt to } \\
\text { market a movie that no one knew about or was excited to begin with. }\end{array}$ \\
\hline \multicolumn{2}{|c|}{ Moral legitimacy } \\
\hline Honesty & $\begin{array}{l}\text { - I love it when companies do it honestly like this. } \\
\text { - I would very much prefer this to a company trying to do some kind } \\
\text { of stealth advertising where they aren't upfront about who they } \\
\text { represent and why they're posting. } \\
\text { - seriously, ALL of the comments seem fake, ALL OF THEM } \\
\text { - I've found that sometimes those sponsored posts have very } \\
\text { misleading titles. }\end{array}$ \\
\hline Selflessness & $\begin{array}{l}\text { - It appears nearly all your posts here on reddit are for self } \\
\text { promotion. } \\
\text { - in the past if you were the creator of the content, posting it to reddit } \\
\text { was taboo. } \\
\text { - looks like he's a blog spammer -- mostly dedicated to "travel ideas." } \\
\text { (and probably attempting to monetize the information he gleans } \\
\text { from Reddit) } \\
\text { - Public broadcasters are not normal corporations. So if Comcast or } \\
\text { some other private company had done this I'd expect you would see } \\
\text { a different reaction from the reddit community. }\end{array}$ \\
\hline \multicolumn{2}{|c|}{ Relational legitimacy } \\
\hline Respect & $\begin{array}{l}\text { - Why do you treat reddit like a bunch of idiots with all the } \\
\text { marketing speak over here? } \\
\text { - People hate advertising generally because it never treats them like } \\
\text { a thinking human being } \\
\text { - Hey Woody, the PR person doing your AMA is kinda obnoxious. } \\
\text { - Importantly, it doesn't treat you like an imbecile or a walking } \\
\text { wallet }\end{array}$ \\
\hline Participation & $\begin{array}{l}\text { - What about interacting with the community instead of just posting } \\
\text { your thoughts on your blog, and posting links to it here } \\
\text { - This mainly applies to people who have zero activity outside their } \\
\text { own app promotion posts, who unfortunately exist around here. } \\
\text { - If they do not contribute to reddit through comments, etc, they are } \\
\text { spammers. } \\
\text { - Not a single question of interest was answered! Woody Harrelson } \\
\text { apparently did not understand the full impact of AMA. Woody, this } \\
\text { is the internet. Not a friendly press conference. }\end{array}$ \\
\hline
\end{tabular}

